\title{
Marina Cañardo, Fábricas de Música. Comienzos de la industria discográfica en la Argentina (1919-1930)
}

Buenos Aires, Gourmet Musical, 2017

\section{Vera Wolkowicz}

\section{OpenEdition}

\section{Journals}

Electronic version

URL: http://journals.openedition.org/transposition/5837

DOI: $10.4000 /$ transposition.5837

ISSN: 2110-6134

Publisher

CRAL - Centre de recherche sur les arts et le langage

Electronic reference

Vera Wolkowicz, "Marina Cañardo, Fábricas de Música. Comienzos de la industria discográfica en la Argentina (1919-1930)", Transposition [Online], 9 | 2021, Online since 15 January 2021, connection on 23 April 2021. URL: http://journals.openedition.org/transposition/5837 ; DOI: https://doi.org/10.4000/ transposition. 5837

This text was automatically generated on 23 April 2021

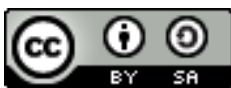

La revue Transposition est mise à disposition selon les termes de la Licence Creative Commons Attribution - Partage dans les Mêmes Conditions 4.0 International. 


\title{
Marina Cañardo, Fábricas de Música. Comienzos de la industria discográfica en la Argentina (1919-1930)
}

Buenos Aires, Gourmet Musical, 2017

\author{
Vera Wolkowicz
}

\section{REFERENCES}

Marina Cañardo, Fábricas de Música. Comienzos de la industria discográfica en la Argentina (1919-1930), Buenos Aires, Gourmet Musical, 2017, 309 p.

1 The boom of the tango record industry in Argentina during the 1920s has not been the subject of a systematic study until now. Marina Cañardo's book Fábricas de Músicas: comienzos de la industria discográfica en la Argentina (1919-1930) is a necessary and original contribution to this topic.

2 The book is structured in nine chapters. As the author clarifies, all the chapters with the exception of the first and the last, begin with a question that is immediately answered by a phrase taken from record advertisements of the time. The types of questions that Cañardo poses cover everything from the making of the records to their distribution in Argentina and France: Who made the records? Who performed on them? How, what and why were they recorded? How were they promoted in Argentina? How were they promoted in France?

In Chapter One the author provides an overview of the record industry in general and of the Argentinian music industry in particular. According to Cañardo, during the 1920s the historical and economic events of World War One favoured non-European markets including Argentina, and by the 1920s, several record companies were already established in the country. Yet there were two that, according to Cañardo, overshadowed the rest: Odeon and Victor, both of which will be the focus of the author througout the book. Even though these companies also recorded other music genres, 
the book centres its discussion on the tango industry, since it was the most successful and profitable genre not only in the South American region, but also abroad. The development of the record industry also produced changes on the musical language of tango and created a star-system similar to Hollywood, in which some singers, such as Carlos Gardel, were idolized. Cañardo's analysis helps the reader understand the connections between the record, radio and film industries, which are discussed in more detail in the following chapters. At the end of the first chapter, the author also highlights some of the conceptual frameworks that underlie her work, such as Bruno Latour's "Actor Network Theory" and Antoine Hennion's "discomorphosis of music." She successfully draws on both these theories in order to understand the network of the record industry in Argentina and the historical process that turned the listening of records into something ordinary and, eventually, habitual.

Chapter Two explores the question of who made the records and describes the two main record companies that were established in Argentina at the beginning of the 1920s. Odeon was originally a German company created in 1903, bought in 1926 by the British company Columbia. In 1919 Max Glücksmann, a European immigrant living and working in Buenos Aires, created the first record factory in Argentina. He began his career by working in a photography company that later expanded into the film industry. He eventually started to get involved in the record business and fostered an association with Odeon, thereby creating a sort of local franchise. However, the 1929 world economic crisis, as well as the development of new technologies such as the radio and the leap from silent film to talkies, brought down the Glücksmann record empire, and by 1934 he lost the exclusivity of the Odeon label. The other company discussed in this chapter is the North American Victor company. Before establishing its first studio in Argentina in 1922, the company had previously done four recording trips in 1907, 1910, 1912 and 1917, in which North American recording specialists were sent to produce recordings of Latin American artists. Prior to the establishment of a factory in Buenos Aires in 1924, however, the recordings made by Victor technicians had to be sent back to the US, where the records were produced. Even though there were other labels in Argentina at the time, these two companies dominated the market.

The following chapter explores the record "star-system" and the development of a "national" music. At the turn of the century, performers were not credited on the first records. But as the new century developed, artists became more relevant. One of the most famous figures of the record industry at this time was the tenor Enrico Caruso. In Argentina, Carlos Gardel, who would become one of the biggest tango stars of all time, had a contract with Odeon. Record companies started to produce exclusivity contracts by which the artists could only record with them. There was also a rise in the production of "recording" orchestras. These were named after the record company and would not perform live except in the recording studio. Cañardo also explains how the artists were paid. In the case of Odeon there was a "stamp system" in which the artist (who might be the performer or the composer of the music) would put a stamp on each printed record. In this way, the company would know how many records were sold and how much it had to pay to its artists. The stamp system was used for famous artists, but session musicians (i.e. those who would only record for specific sessions) were paid per recording instead of by record produced.

6 In Chapter Four, Cañardo explains the recording process and the technological improvements that accompanied it. The recording studios were called "laboratorios de 
impresiones" ("recording laboratories"). The technology of the record industry before the invention of the microphone, which would be first used in Argentina by Victor in 1926, used different recording techniques to obtain an "equalized" sound at the moment of being recorded. Cañardo mentions that the pianos were usually positioned higher than the rest of the instruments, and sometimes the singers and other musicians had to be very close to each other in order to produce the desired volume. Recordings were made once and in one take. The appearance of the microphone in 1926 not only facilitated the process of recording, but also influenced the styles of music recorded. Therefore, in tango recordings the use of an "estribillista" (like a jazz crooner) would become more common in orchestral tangos, which incorporated a singer just to perform the refrain.

7 Chapter Five is dedicated to describing how music styles were labelled. Victor divided records by label colour. The records under the black label featured popular music mainly tangos, but also other folk national genres-, while the red label was used for recordings of classical music. In contrast, Max Glücksmann's Odeon divided the records into three categories: "cantados" (sung), "instrumentales" (instrumental music) and "orquestas" (orchestras). Classical music records were more expensive than popular music and were aimed at a different social class. Moreover, classical music records were produced abroad, while popular music was recorded locally. By looking at the genres produced by these companies, the author thus produces her own division of musical styles into three categories: tango, other Argentinian folk genres, and foreign genres (which would usually include jazz bands). There were also other types of recordings at the time, although these were not produced en masse, such as hymns and patriotic marches, or even important speeches by relevant public figures.

In Chapter Six, Cañardo shows the readers how the dance industry went hand in hand with the record industry. Record companies would produce music labelled "bailables" (danceable) and would have their own orchestras (as mentioned in Chapter Two) to produce it.

9 In Chapter Seven, the author goes on to explain how records were promoted in Argentina. The discourse about "national" music seems to have been essential as a strategy to sell tangos. According to Cañardo, many Argentine intellectuals were against this genre, claiming that the true expression of national music was rural folk music and arguing that tango degraded moral and spiritual values. This kind of discourse had supporters from both left- and right-wing intellectuals. Yet tango also had its defenders. Under this perspective, Florencia Garramuño defines this music as a "primitive modernity." Record companies thus used the terms "national" and "criollo" (creole) on tango recordings as a marketing strategy appealing to an imaginary sense of nationality that would include tango in this folkloric fantasy.

Chapter Eight explores the reception and circulation of tango in France, more specifically in Paris. The author here puts into question the idea that tango was accepted back in Argentina after its success in the French capital. She shows how tango was a boom in Paris before World War One and reappeared with new emphasis after the war. She also shows how musicians used the "exotic and erotic" portrayal of tango to appeal to French audiences. According to Cañardo, this strategy was not just a response to a fleeting fashion, but rather emerged because foreign musicians did not have a right to perform in France unless they appeared as an "attraction" or "variety show." Possibly because of Valentino and the influence of Hollywood, tango musicians would 
dress as gauchos (i.e. countrymen, or Argentine "cowboys") instead of performing with the typical suits that would be more common in any performance in Argentina in order to sustain this exotic imaginary that French audiences would expect. Tango was commercialized in France mainly through the record companies Pathé and the French Odéon (associated with Max Glücksmann and the Argentine Odeon). The people recording these tangos were mostly not Argentinean, so when an Argentine conductor was leading the orchestra, the record companies would label these recordings as "authentic."

11 The final chapter gives a general overview of the power of the record industry from its first recordings to the realities of the present with mp3 technologies and online streaming and the disappearance of material culture. As Cañardo points out, even if the platform used for reproducing music has changed, the sound can be revived over and over, immortalizing musics that will never disappear.

Cañardo's book is impeccable. She writes in a very engaging way and connects each topic of the book seamlessly not only through the text, but also visually with images that illustrate her written words. So far, research on tango has centred on the music, and there have not been any studies that would explain the expansion of a genre that eventually reached almost every corner of the world. The origins of this success are shown through the connection between the music and the record industry, which at the same time fed into other mass media outlets such as radio broadcasting, film and the dance industry. Thus, Cañardo's book becomes an essential reading not only for people interested in tango, but for those who want to know about the beginnings of the record industry in Argentina and the surrounding region.

\section{NOTES}

1. GARRAMUÑo, Florencia, Modernidades primitivas. Tango, samba y nación, Buenos Aires, Fondo de Cultura Económica, 2007, cited in CAÑARDo, p. 218.

\section{AUTHORS}

\section{VERA WOLKOWICZ}

Vera Wolkowicz holds a PhD and an MPhil in Music from the University of Cambridge and a BA from the University of Buenos Aires. Her research focuses on Latin American musical nationalisms at the turn of the twentieth century. She is the author of Música de América. Estudio preliminar y edición crítica (2012) and co-author with Silvina Mansilla of Carlos Guastavino. Músicas Inéditas (2012). She has also published book chapters and papers in scientific journals on Italian 
opera in Buenos Aires, and on music criticism in early twentieth-century Argentina, Peru and Ecuador. She has been an Early Career Fellow 2018/19 at the Institute of Musical Research (Royal Holloway, University of London), and is currently an Affiliated Researcher at the Instituto de Artes del Espectáculo “Dr. Raúl H. Castagnino”, Facultad de Filosofía y Letras, Universidad de Buenos Aires as part of the project "Historias socio-culturales del acontecer musical de la Argentina (1890-2000)". 